\title{
Pengembangan Instrumen Evaluasi Pembelajaran Kurikulum 2013 Berbasis Multimedia pada Materi Fisika SMA Kelas X
}

\author{
Maria Dewati ${ }^{1}$, Halleyna Widyasari ${ }^{2}$ \\ ${ }^{12}$ Fakultas Teknik, Matematika dan Ilmu Pengetahuan Alam \\ Universitas Indraprasta PGRI, Jakarta \\ e-mail: ${ }^{1}$ merr_d@yahoo.co.id, ${ }^{2}$ halleynawidyasari0@gmail.com
}

\begin{abstract}
The use of multimedia in learning is considered necessary today, especially digital-based multmedia, can have a positive impact in the world of education, especially on students and teachers. The purpose of this study designed the evaluation of learning instruments in accordance with the curriculum 2013 based on digital multimedia in the material Physics High School class X semester I in SMAN 51 and SMAN 104 East Jakarta academic year 2017/2018. Type of Research \& Development $(R \& D)$ research with ADDIE development model (analyze, design, development, implementation, evaluation), validation subjects consist of a curriculum expert, two media teachers, four students for individual trials, ten students for small group trials, and thirty students for lapnography test.Data collection methods used questionnaires.Data analysis technique used qualitative descriptive analysis technique.The result of this research is soft file physics evaluation problem which is packed in flash program. The validity of the instrument is:(1) according to the expert review of the curriculum with good category $82.5 \%,(2)$ according to the review of the subject teachers are in good category $87.5 \%$, (3) good $92.5 \%$, (4) based on a good category individual test $84.8 \%$, (5) based on small group good trials $81.5 \%$ and (6) field with good category $83.7 \%$ Learning evaluation instrument Curriculum 2013 based on digital multimedia is not revised, can be implemented in schools and for further research
\end{abstract}

Keywords: learning evaluation instrument, multimedia, curriculum 2013, ADDIE model

Abstrak: Penggunakan multimedia dalam pembelajaran dianggap perlu saat ini, terutama multmedia berbasis digital,dapat berdampak positif dalam dunia pendidikan terutama pada siswa dan guru.Tujuan penelitian ini mendesain instrumen evaluasi pembelajaran yang sesuai dengan kurikulum 2013 berbasis multimedia digital pada materi Fisika SMA kelas X semester I di SMAN 51 dan SMAN 104 Jakarta Timur tahun pelajaran 2017/2018. Jenis penelitian Research \& Development ( R\&D) dengan model pengembangan ADDIE (analyze, design, development, implementation,evaluation) ,Subyek validasi terdiri dari seorang ( ahli kurikulum, ahli media), dua guru bidang studi, empat siswa untuk uji coba perorangan, sepuluh siswa untuk uji coba small group, dan tiga puluh siswa untuk uji lapngan.Metode pengumpulan data menggunakan angket. Teknik analisis data yang digunakan teknik analisis deskriptif kualitatif. Hasil penelitian adalah soft file soal-soal evaluasi fisika yang dikemas dalam program flash. Validitas instrumen adalah:(1)menurut review ahli kurikulum dengan kategori baik (82,5\%),(2) menurut review guru bidang studi berada pada kategori baik $(87,5 \%),(3)$ menurut review ahli media dengan kategori sangat baik (92,5\%),(4)berdasarkan uji coba perorangan dengan kategori baik(84,8\%), (5) berdasarkan uji coba small group dengan kategori baik(81,5\%), dan (6) berdasarkan uji coba lapangan dengan kategori baik(83,7\%) Instrumen evaluasi pembelajaran Kurikulum 2013 berbasis multimedia digital ini tidak direvisi, dapat diimplementasikan di sekolah dan untuk penelitian lebih lanjut.

Kata kunci: instrumen evaluasi pembelajaran, multimedia, kurikulum 2013, model ADDIE 


\section{Pendahuluan}

Pendidikan menjadi salah satu penopang penting dari kemajuan suatu bangsa, sebab secara harfiah makna pendidikan mengacu pada suatu proses pengubahan sikap dan tata laku seseorang atau kelompok dalam usaha untuk mendewasakan manusia melalui upaya pengajaran dan pelatihan (KBBI, 2007). Sehingga pendidikan yang baik akan mengarahkan mobilitas sosial masyarakat pada hal-hal yang bernilai positif. Mengembangkan kemampuan serta perilaku yang mendorong individu untuk selalu berorientasi pada pemikiran "apa peranannya dalam kehidupan". Namun, potret pendidikan di Indonesia saat ini masih tergolong memprihatinkan. Sementara permasalahan yang paling mendasar terkait hal tersebut masih terpusat pada tingkat kualitas atau pendidikan, meski Indonesia sudah mengenal sistem pendidikan atau kurikulum sudah lama. Berdasarkan data statistika, gambaran mutu pendidikan di Indonesia masih terbilang rendah. Pertama, data Badan Pusat Statistika RI, menyebutkan bahwa Indeks Pembangunan Manusia (IPM)- dalam kurun waktu 4 tahun terakhir tidak terjadi perubahan yang signifikan. Pada tahun 2010 skor IPM sebesar 66,53 dan tahun 2014 IPM hanya naik tipis menjadi 68,90. Hal tersebut menggambarkan bahwa pendidikan di Indonesia belum sepenuhnya memberikan perubahan perilaku masyarakat, terutama pada komponen dasar pengetahuan yang diindikasikan dengan angka melek huruf dan rata-rata lama sekolah. Hingga tahun 2013 masih ditemukan masyarakat yang tidak sekolah sebesar $5.77 \%$, tidak tamat SD sebesar $14.13 \%$, dan tamat SD sebesar $28.18 \%$. Sementara yang menamatkan sekolahnya hingga tingkat pendidikan dasar setara SMP sebesar 20.51\% dan setara SMA sebesar 31.41\%. Kondisi tersebut dapat disebabkan oleh adanya faktor penghambat. Dalam dunia pendidikan, faktor penghambat biasanya dikenal dengan istilah faktor distorsi. Munculnya faktor distorsi dalam sistem pendidikan akan memberikan dampak buruk secara langsung terutama dalam pengelolaan dan peningkatan mutu pendidikan (Al Mawadi, 2007). Secara makna, dalam UU no. 20 tahun 2003 tentang Sistem Pendidikan Nasional Bab 1 Pasal 1 Ayat 1 dijelaskan bahwa evaluasi pendidikan mengandung pengertian sebagai suatu kegiatan pengendalian, penjaminan, dan penetapan mutu pendidikan terhadap berbagai komponen pendidikan pada setiap jalur , jenjang, dan jenis pendidikan sebagai bentukrtanggungjawaban penyelenggaraan pendidikan. Secara sederhana, evaluasi pembelajaran dapat dikatakan sebagai tindakan yang dilakukan untuk mengukur atau menilai tingkat keberhasilan dari kegiatan belajar mengajar (KBM).Adapun tujuan dari evaluasi pembelajaran secara umum dapat dikatakan sebagai salah satu sarana untuk mengetahui efektivitas proses pembelajaran yang telah dilaksanakan, melalui indikator efektivitas yang dapat dilihat dari perubahan tingkah laku peserta didik. Sedangkan secara khusus, evaluasi pembelajaran bertujuan untuk mengetahui tingkat penguasaan peserta didik terhadap kompetensi yang telah ditetapkan, mengetahui kesulitan yang dialami peserta didik, dan mengetahui efisiensi serta efektivitas strategi pembelajaran yang digunakan oleh pendidik. (Zainal, 2010). Adapun metode pembelajaran di Indonesia masih banyak yang menggunakan metode konvensional, dan masih sangat minim untuk mulai menggunakan metode inovatif dengan menggembangkan beberapa multimedia interaktif, siswa masih banyak memperoleh informasi dari buku atau media cetak dan materi yang disampaikan oleh guru secara langsung. Namun saat ini pemerintah mulai berusaha mengantarkan masyarakat pada pembelajaran berbasis multimedia. Hal tersebut diharapkan mendorong munculnya inovasi dalam proses pembelajaran yang menarik, serta dapat dipelajari secara mandiri, praktis, dan mudah diakses. Alasan penggunakan multimedia pada proses evaluasi sangat menghemat anggaran, mengurangi kesalahan cetak soal, Keamanan dan kerahasiaan soal tes lebih terjamin karena untuk mengakses diperlukan password yang hanya diketahui oleh peserta tes (ujian). Salah satu contohnya adalah adanya instrumen 
evaluasi Computer Assist Test (CAT).Penelitian ini dirancang untuk mengembangkan instrumen evaluasi pembelajaran pada kurikulum 2013 berbasis multimedia di tingkatan Sekolah Menengah Atas dengan subjek materi pembelajaran Fisika. Penelitian kali ini lebih ditekankan pada proses evaluasi hasil pembelajaran. Tujuan akhirnya tak lain adalah sebagai dasar memperbaiki kualitas pembelajaran pada materi pembelajaran Fisika. Penelitian ini dibuat menggunakan multimedia berbasis komputer dengan menggunakan program Flash, dan digunakan untuk melihat bagaimana tingkat efektifitas evaluasi pembelajaran fisika di sekolah. Materi pembelajaran Fisika selama ini dianggap sulit bagi sebagian siswa karena pembelajaran fisika tidak hanya berbicara tentang pemahaman (knowlegde) tetapi lebih luas dari itu Fisika lebih menekankan kepada 3 aspek yaitu Fisika sebagai "body of knowledge", merupakan kumpulan pengetahuan atau produk dalam bentuk fakta, konsep, prinsip, teori, hukum yang tersusun secara sistematis.Fisika sebagai proses, yakni proses dari upaya manusia untuk memahami berbagai gejala alam dalam bentuk langkah-langkah, prosedur, bahkan sistem dalam mendapatkan produk.Fisika memiliki kecenderungan tindakan dalam melakukan kegiatan ilmiah seperti ketekunan, objektivitas. Sehingga belajar Fisika adalah belajar yang mengembangkan 3 ranah (pengetahuan, sikap, keterampilan) dan hal ini sesuai dengan Kurikulum 2013 dengan mengembangkan pengalaman belajar yang memberikan kesempatan luas bagi peserta didik untuk menguasai kemampuan intelektual, sikap, dan keterampilan. Peserta didik diharapkan mampu mengembangkan kompetensinya secara menyeluruh, dari pemahaman, mengingat, menjelaskan, menganalisa,mengevaluasi dan mencipta, oleh karena itu di perlukan model pembelajaran yang tepat dan soal/intrumen evaluasi pembelajaran dengan tepat, soal evaluasi yang mudah dalam pengerjaanya, memiliki fleksibilitas yang tinggi ( waktu bebas, tempat pengerjaan dimana saja), tanpa harus meninggalkan aspek kemampuan kognitif siswa, mengajarkan siswa belajar mandiri dan meningkatkan kemampuan berpikir tingkat tinggi siswa, sehingga siswa lebih mudah memaknai pembelajaran yang di peroleh disekolah. Penggunaan multimedia dalam proses pembelajaran, adalah untuk menyalurkan pesan (pengetahuan, ketrampilan dan sikap) serta dapat merangsang pikiran, perasaan, perhatian dan kemauan yang belajar sehingga secara sengaja proses belajar terjadi, bertujuan dan terkendali.Multimedia berbasis digital dengan menggunakan program Flash adalah salah cara yang bisa digunakan untuk mempermudah siswa mengerjakan soal-soal evaluasi pembelajaran pada materi fisika, siswa dapat latihan soal-soal fisika dengan mudah tanpa harus menunggu di perintah atau tugas dari guru dan sekolah.Hal ini di pertegas oleh (Steinberg, 1991) CAI(Computer Assisted Instruction), instruksi pembelajaran dengan bantuan komputer memiliki karakteristik yang khas : menekankan belajar mandiri, interaktif, dan menyediakan bimbingan.

\section{Metode penelitian}

Penelitian ini berjenis pengembangan Research \& Development ( $R \& D)$ dengan model ADDIE (analyze,design, development,implementation,Evaluasi).Adapun subyek validasi terdiri 1 (satu) orang ahli materi dan kurikulum,1 (satu) orang ahli media pembelajaran, 2 (dua) orang guru bidang studi fisika, 4 (empat) orang siswa untuk uji coba one by one (perorangan), 10 (sepuluh) orang siswa untuk uji coba small group (kelompok kecil), 30 (tiga puluh) orang siswa untuk uji coba lapangan big group (kelompok besar). Siswa yang menjadi subyek validasi adalah 2 (dua) sekolah Menengah Atas (SMAN 51, SMA104) kelas X. Adapun alur pelaksanaan pemodelan ADDIE dalam penelitian ini sebagai berikut 


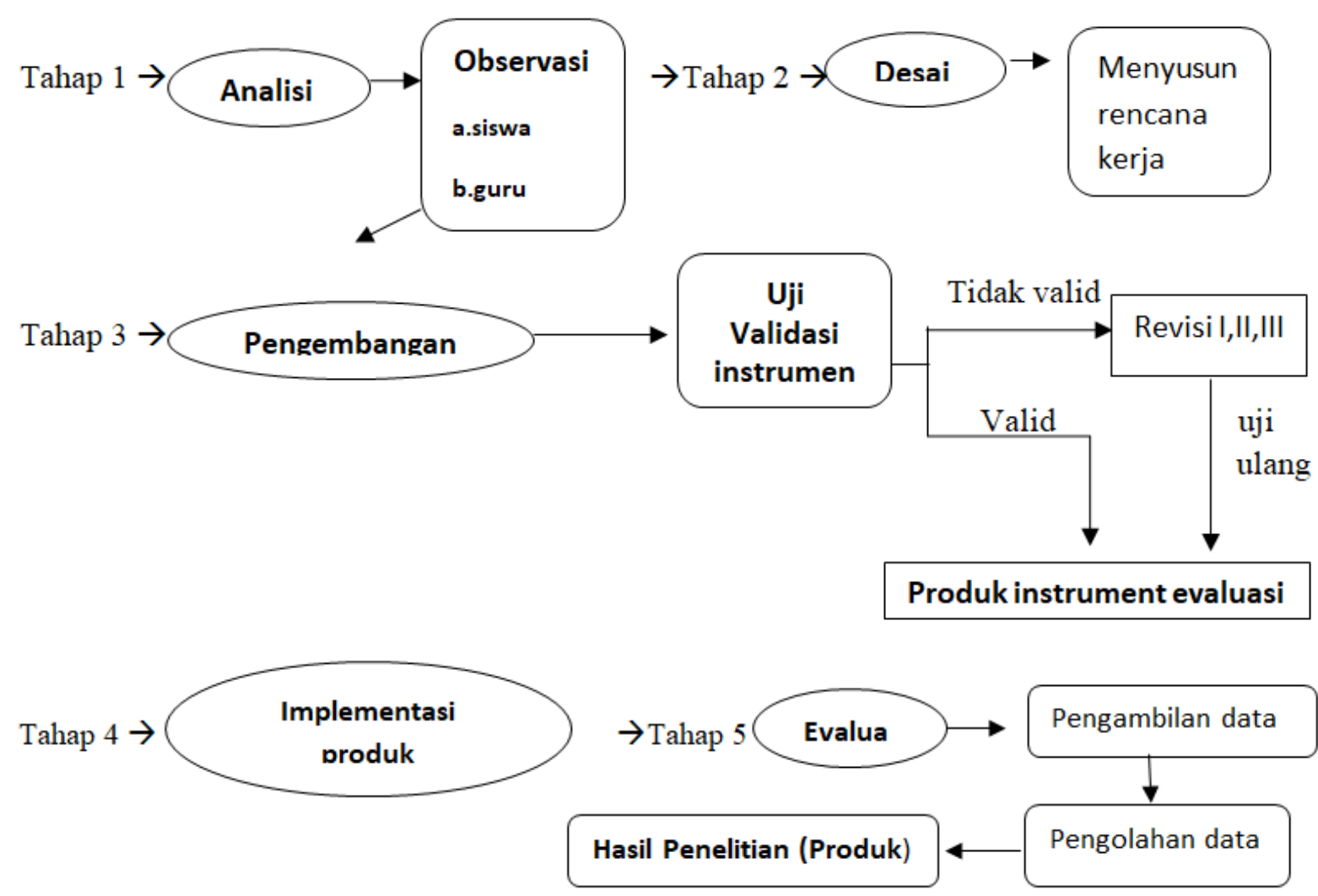

Gambar 1 : Desain alur penelitian

Keterangan dari gambar 1 desain alur penelitian adalah sebagai berikut

Tahap 1 : Analisis $\rightarrow$ peneliti melakukan observasi dengan wawancara kepada guru bidang studi materi fisika, siswa-siswa kelas X SMA. Tahap 2: desain $\rightarrow$ peneliti menyusun rencana kerja untuk merancang bentuk tampilan \& isi, membuat instrumen validasi. Tahap 3: Pengembangan $\rightarrow$ menguji program ke ahli media, ahli materi \& kurikulum, dan guru di sekolah. Tahap 4 : Implementasi $\rightarrow$ Produk diujikan ke sekolah.Tahap 5: Evaluasi $\rightarrow$ Produk diujikan disekolah untuk pengambilan data, pengolahan data untuk mendapatkan hasil penelitian. Metode pengumpulan data yang digunakan dalam penelitian ini angket dan kuesioner. Metode angket/kuesioner dengan menggunakan instrument validasi produk kuesioner, yang nantinya sebagai data review yang diperoleh dari para ahli dan siswa yang terlibat sebagai reviewer dalam penelitian ini.

Jenis pengolahan data yang didapat dari penelitian adalah data kualitatif. Data tersebut akan diolah (analisis) dengan menggunakan teknik analisis deskriptif.

\section{Hasil dan pembahasan}

Berdasarkan hasil wawancara dan review dokumen peneliti dengan siswa dan guru di sekolah SMA 51 \& 104, bahwa 1)sarana laboratorium komputer hanya di gunakan untuk praktikum bidang studi teknologi informatika . 2) Evaluasi pembelajaran siswa yang menggunakan media komputer hanya untuk kelas XII, karena instrumen soal yang sudah di setting dari Dinas Pendidikan dan Kebudayaan. 3) Evaluasi pembelajaran siswa untuk kelas X \& XI masih menggunakan paper test. 4)Guru tidak dapat mengontrol aktivitas siswa terhadap frekwensi siswa belajar mengerjakan soal-soal di luar sekolah. 5) Kecenderungan siswa belajar pada saat mendapat tugas pekerjaan rumah yang diperintah oleh guru bidang studi. 
6)Kecenderungan siswa mengerjakan soal-soal latihan sesuai dengan materi yang sudah diajarkan oleh guru sekolah, sehingga terlihat kurang adanya usaha dari siswa untuk belajar mandiri. Berdasarkan hasil wawancara tadi, maka peneliti membuat tampilan program sesuai gambar-gambar berikut :

1. Tampilan di bagi menjadi 2 bagian yaitu, Halaman Administrasi (peneliti/guru) pemasok soal-soal fisika kelas $\mathrm{X}$ dan mengetahui nilai yang di dapat oleh siswa

2. Halaman siswa yang sudah di susun berdasarkan nomer induk siswa, dan siswa bisa melakukan login dan mengisi biodatanya.

\section{ADMINISTRASI}

username

Passworc

Q SIGN IN

\section{RUANG SISWA}

\section{|NIS}

Password

\section{Q SIGN IN}

Gambar 3. Halaman Login Siswa
Gambar 2. Halaman Login Administrasi
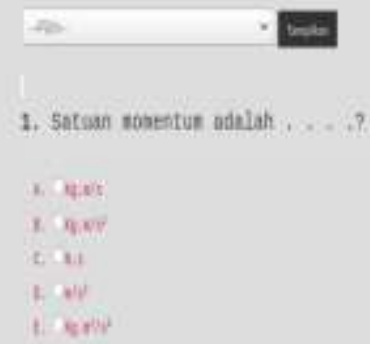

Gambar 4. Tampilan soal-soal

Setelah uji coba produk penelitian dengan ahli media pembelajaran untuk melihat tampilan program , ahli materi \& kurikulum untu melihat kesesuaian dengan kurikulum 2013, dan guru bidang studi fisika kelas $\mathrm{X}$, maka didapatkan persentase hitungan capaian berdasarkan jawaban yang diberikan oleh ahli pada validasi instrumen penelitian pengembangan ini. Seperti ditunjukkan pada tabel 1 :

\begin{tabular}{|c|c|c|c|c|c|}
\hline No & Nama Ahli/pakar & Jmlh soal & Skor Tertinggi & Nilai perolehan & $\%$ \\
\hline 1 & $\begin{array}{l}\text { Ahli } \\
\text { media }\end{array}$ & 10 & 4 & 37 & $92,5 \%$ \\
\hline 2 & $\begin{array}{l}\text { Ahli } \\
\text { kurikulum }\end{array}$ & 22 & 4 & 73 & $82,5 \%$ \\
\hline 3 & $\begin{array}{l}\text { Ahli } \\
\text { Materi/guru }\end{array}$ & 28 & 4 & 98 & $87,5 \%$ \\
\hline
\end{tabular}

Berdasarkan hasil uji coba validasi instrument yang telah dinilai oleh ketiga ahli (media, kurikulum dan guru), maka penelitian sudah baik, tidak perlu di revisi dan bisa diteruskan untuk Uji coba produk ke subyek berikutnya yaitu siswa-siswa SMA 51 dan SMA 104 
setelah mengerjakan soal dan mengisi instrumen validasi dengan hasil yang ditunjukkan sebagai berikut pada tabel 2:

\begin{tabular}{lllllc}
\hline $\begin{array}{c}\text { Jmlh } \\
\text { siswa }\end{array}$ & \multicolumn{1}{c}{$\begin{array}{c}\text { Nama } \\
\text { kelompok }\end{array}$} & $\begin{array}{c}\text { Jmlh } \\
\text { soal }\end{array}$ & $\begin{array}{c}\text { Skor } \\
\text { Tertinggi }\end{array}$ & $\begin{array}{c}\text { Total Nilai } \\
\text { perolehan }\end{array}$ & $\%$ \\
\hline 4 & $\begin{array}{l}\text { One by one } \\
\text { (perorangan) }\end{array}$ & 23 & 4 & $339,2 \%$ & $84,8 \%$ \\
\hline 10 & $\begin{array}{l}\text { Small group } \\
\text { (Kel Kecil) }\end{array}$ & 23 & 4 & $815 \%$ & $81,5 \%$ \\
\hline 30 & $\begin{array}{l}\text { Big group } \\
\text { (kel Besar) }\end{array}$ & 23 & 4 & $2511 \%$ & $83,7 \%$ \\
\hline
\end{tabular}

Penilaian yang diberikan siswa perorangan atau one by one berkisar pada skor 3 (baik) dan 4 (sangat baik) sehingga program flash yang berisikan soal-soal evaluasi fisika valid, tetapi pada penilaian small group ( kelompok kecil), yang terdiri 40\% siswa yang berprestasi belajar rendah cenderung nilainya kecil, karena adanya kesulitan menjelaskan pada saat pengarahan tata cara penilaian, sehingga adanya tidakpahaman siswa dalam memberi nilai, tetapi penilaian secara keseluruhan program flash baik atau valid, kemudian penelitian berlanjut kepada kelompok besar (uji lapangan) yang terdiri 60\% siswa berprestasi tinggi, dan hasil pengujian bernilai baik dan dianggap vali seperti yang tercantum pada tabel 2.Penilaian yang diberikan siswa sangat bervariasi. Beberapa siswa memberikan skor tinggi pada kejelasan paparan materi dan kejelasan tampilan materi, sedangkan beberapa siswa lainnya memberikan skor yang tinggi pada aspek-aspek yang lain, sehingga pengembangan instrumen evaluasi berbasis multimedia ini valid menurut uji coba lapangan. Secara umum multimedia interaktif ini tidak perlu direvisi dan siap digunakan untuk penelitian lebih lanjut.

\section{Simpulan dan Saran}

Berdasarkan hasil dan pembahasan, maka dapat disimpulkan sebagai berikut: 1) pemanfaatan multimedia dalam proses pelaksanaan evaluasi di sekolah, dibutuhkan oleh siswa dan guru, karena selain memudahkan siswa melatih keterampilan mengerjakan soal-soal latihan, siswa lebih mandiri dan siswa lebih siap menghadapi ujian-ujian sekolah seperti ujian semester ataupun ujian nasional, dan guru juga lebih mudah meyiapkan soal-soal ujian dengan menggunakan komputer, lebih menghemat tenaga dan biaya.

Validasi yang didapat dari penilaian para ahli media (92,5\%), ahli kurikulum ( 83,5\%), dan ahli materi/guru $(87,5 \%)$ penelitian ini dianggap baik. Validasi yang didapat dari siswa pada uji lapangan baik perorangan ( 84,5\%), kelompok kecil ( $81,5 \%)$ dan kelompok besar $(83,7 \%)$, maka peneilitian dianggap baik dan valid. Sehingga dapat dilanjutkan untuk penelitian selanjutanya .

\subsection{Saran}

Saran yang peneliti sampaikan dalam makalah ini adalah: pertama, kepada pihak sekolah yang diteliti perlu terus memperbaiki dan menambah sarana belajar dan memberikan kesempatan guru untuk mengembang kompetensinya terutama di bidang teknologi informatika, kegiatan pembelajaran bisa maksimal dan supaya dapat menghasilkan hasil belajar fisika yang baik. Kedua, kepada para siswa untuk lebih rajin belajar mandiri dan kelompok baik di rumah maupun di sekolah. Sebab sebaik apapun media dan sarana yang ada bila peserta didiknya tidak maksimal belajar, maka tujuan dari pembelajaran tidak akan tercapai dan hasil belajar akan kurang terus. Ketiga, kepada guru yang sekolahnya diteliti agar terus menambah wawasannya terutama di bidang ilmu teknologi informatika dan sains agar proses belajar mengajar mampu membantu siswa dalam pemaham konsep belajarnya, 
sehingga hasil belajar siswa tidak terus dalam posisi rendah tetapi adanya peningkatkan dan tujuan daripada pendidikan nasional tercapai. Keempat, kepada peneliti untuk bisa melanjutkan penelitiannya dengan mengembangkan aplikasi multimedia ini tidak hanya berbasis digital dan komputer tetapi dengan media online lainnya seperti menggunakan system android sehingga bisa diakses bagi semua siswa SMA dan terus menambah bank soal untuk semua kelas di SMA.

\section{Daftar Pustaka}

Almawadi. 2007. Upaya Peningkatan Mutu Pendidikan di Madrasah Aliyah Negeri Maguwoharjo Sleman Yogyakarta. Skripsi :UIN Sunan Kalijaga Yogyakarta.

Borg W.R., Gall P Joyce \& Gall M.D.1989. Educational Research. New York: Pearson Education

Departemen Pendidikan Nasional. 2008. Panduan Pengembangan Bahan Ajar. Jakarta:Departemen Pendidikan

Heinich, Molenda, Russell, Smaldino. 1996. Instructional Media and Technologies for learning. Prentice Hall, Engelwood, New Jersey

Temiz, Tasar\& Tan. 2006. Development and Validation of a multiple format test of Science Process Skills. International Educational Journals, 7 (7), 1007-1027

WenaMade.2010.Strategi Pembelajaran Inovatif Kontemporer: suatu tinjauan konseptual operasional. Jakarta :BumiAksara 